\title{
The second aconitase (AcnB) of Escherichia coli
}

\author{
Alan J. Bradbury, ${ }^{1}$ Megan J. Gruer, ${ }^{1}$ Kenneth E. Rudd ${ }^{2}$ \\ and John R. Guest ${ }^{1}$
}

Author for correspondence: John R. Guest. Tel: +44 114276855 ext. 4406 . Fax: +44 1142728697.

\footnotetext{
1 The Krebs Institute for Biomolecular Research, Department of Molecular Biology and Biotechnology, University of Sheffield, Western Bank, Sheffield S10 2UH, UK

2 National Center for Biotechnology Information, National Library of Medicine, National Institutes of Health, Bethesda, MD 20894, USA
}

\begin{abstract}
The second aconitase (AcnB) of Escherichia coli was partially purified from an acnA:: $\operatorname{kan}^{\mathrm{R}}$ mutant lacking AcnA, and the corresponding polypeptide identified by activity staining and weak cross-reactivity with AcnA antiserum. The acn B gene was located at $2.85 \mathrm{~min}(131.6 \mathrm{~kb})$ in a region of the chromosome previously assigned to two unidentified ORFs. Aconitase specific activities were amplified up to fivefold by infection with $\lambda$ acnB phages from the Kohara $\lambda-E$. coli gene library, and up to 120 -fold ( $50 \%$ of soluble protein) by inducing transformants containing a plasmid (pGS783) in which the acnB coding region is expressed from a regulated 77 promoter. The AcnB protein was purified to $\geqslant 98 \%$ homogeneity from a genetically enriched source (JRG3171) and shown to be a monomeric protein of $M_{r} 100000$ (SDS-PAGE) and 105000 (gel filtration analysis) compared with $M_{r} 93500$ predicted from the nucleotide sequence. The sequence identity between AcnA and AcnB is only $17 \%$ and the domain organization of AcnA and related proteins (1-2-3-linker-4) is rearranged in AcnB (4-1-2-3).
\end{abstract}

Keywords: aconitase, Eschericbia coli, citric acid cycle, iron-sulphur proteins, protein domains

\section{INTRODUCTION}

Aconitase (EC 4.2.1.3) catalyses the reversible isomerization of citrate and isocitrate via cis-aconitate in the citric acid and glyoxylate cycles. Aconitases are monomeric enzymes having a single [4Fe-4S] centre that is essential, but has no redox function in catalysis. Recent studies have shown that Escherichia coli contains at least two aconitases, $A c n A$ and $A c n B$ (Gruer \& Guest, 1994). The gene (acn $A)$ encoding the first enzyme to be purified (AcnA, $M_{\mathrm{r}}$ $97500)$ was located at $28 \mathrm{~min}(1350 \mathrm{~kb})$ on the physical map of the E. coli chromosome, and AcnA specific activity could be amplified up to 200 -fold in phagemid-containing strains.

The AcnA protein was purified to homogeneity from both wild-type and genetically amplified sources (Prodromou et al., 1991; Bennett et al., 1995). Studies with acn $A-$ lac $Z$ fusions have shown that expression of the acn $A$ gene is subject to cAMP receptor protein (CRP)mediated catabolite activation, ArcA-and FNR-mediated anaerobic repression, iron and Fur-dependent activation, superoxide and SoxRS-dependent activation and RpoS-

Abbreviations: CRP, CAMP receptor protein; IPMI, isopropylmalate isomerase; IRP, iron-regulatory protein. mediated stationary-phase activation (Gruer \& Guest, 1994; M. J. Gruer \& J. R. Guest, unpublished observations). The primary structure of $A \operatorname{cn} A$ deduced from the nucleotide sequence of the acn $A$ gene showed that the $E$. coli enzyme is structurally related to the porcine mitochondrial aconitase (Prodromou et al., 1992; Robbins \& Stout, 1989). Some 19 of the 20 active-site residues, including three cysteine residues involved in ligand binding to the $[4 \mathrm{Fe}-4 \mathrm{~S}]$ centre, are conserved and the overall sequence identity is $29 \%$. AcnA is also $20-21 \%$ identical to the bacterial and fungal isopropylmalate isomerases (IPMIs) which catalyse the reversible isomerization of $\alpha$-isopropylmalate and $\beta$-isopropylmalate via dimethylcitraconate in the leucine biosynthetic pathway (Prodromou et al., 1992). The fungal IPMIs resemble Acn $\mathrm{A}$ and other aconitases in being monomeric and in containing four colinear structural domains with a long interdomain linker extending between domains 3 and 4 . In contrast, bacterial IPMIs are heterodimers expressed from adjacent genes (leuCD) that encode products corresponding to the three $\mathrm{N}$-terminal domains of $\mathrm{Acn} A$ and an untethered C-terminal domain, but no linker (Rosenthal \& Calvo, 1990; Prodromou et al., 1992). The AcnA protein is even more closely related (53\% identity) to the mammalian iron regulatory proteins (IRPs) or iron regulatory factors (IRFs). Depending on the availability of iron, these proteins exist either as apo-proteins or 
[4Fe-4S]-containing holo-proteins, each form having a distinct and mutually exclusive function. During irondepletion, IRP adopts the enzymically inactive apoprotein conformation, which regulates translation by binding to the iron-responsive elements (IREs) of relevant transcripts, whereas during iron-sufficiency IRP becomes the $[4 \mathrm{Fe}-4 \mathrm{~S}]$-containing cytoplasmic aconitase which no longer binds IRE. It is postulated that IRP may sense iron availability through the continuous assembly and disassembly of the [4Fe-4S] cluster, and that assembly of the [4Fe-4S] cluster induces a conformational change such that the IRE-binding site of IRP becomes inaccessible to RNA (Klausner \& Rouault, 1993; Gray et al., 1993; Emery-Goodman et al., 1993; Hirling et al., 1994). Recently, a second [4Fe-4S]-containing IRP $\left(\operatorname{IRP}_{\mathrm{B}}\right)$ has been identified but in this case the holo-protein lacks aconitase activity (Henderson et al., 1993; Guo et al., 1994).

In E. coli, a second aconitase (AcnB) was detected as the residual activity of a mutant (JRG2789) in which the chromosomal acn $A$ gene had been disrupted by inserting a $k a n^{\mathrm{R}}$ cassette (Gruer \& Guest, 1994). This enzyme resembled other iron-sulphur containing aconitases in being unstable and reactivatable by ferrous ions under reducing conditions. The present paper describes the partial purification of $A c n B$ from the $a c n A::$ kan ${ }^{\mathrm{R}}$ mutant, the identification of the $a \mathrm{cn} B$ gene, and the purification of AcnB from amplified sources to near homogeneity. AcnB is related to $A \mathrm{cn} A$ ( $17 \%$ sequence identity) and shows an interesting domain rearrangement (4-linker-1-2-3) relative to Acn A and other aconitases (1-2-3-linker-4).

\section{METHODS}

Bacterial strains, plasmids, phagemids and bacteriophages. The routine transformation host for all phagemids was $E$. coli DH5 $\alpha$ (Hanahan, 1983); derivatives of E. coli DH1 (Sambrook et al., 1989) containing two plasmids (pGS799 and pGS801, see below) were used in specific growth tests, DH1(pGS801) being designated JRG3171; JRG3099 is a transformant of E. coli BL21/ $\lambda$ DE3 containing the expression plasmid, pGS783 (see below). The acn $A:$ : kan ${ }^{R}$ mutant (JRG2789) is a derivative of $E$. coli W3110 in which a $1.04 \mathrm{~kb}$ segment of the chromosomal acn $A$ coding region is replaced by a $1.3 \mathrm{~kb} \mathrm{kan}^{\mathrm{R}}$ cassette (Gruer $\&$ Guest 1994). Phages $\lambda 4 \mathrm{D} 12, \lambda 4 \mathrm{E} 11$ and $\lambda 17 \mathrm{C} 11$ (112-114 in the mini-set of Kohara et al., 1987) were used in infection experiments and to generate the pUC118-derivatives pGS799 and pGS801 (Fig. 1). The acnB expression plasmid (pGS783) was constructed by PCR-amplification of the $a c n B$ coding region from JRG2789 chromosomal DNA with the simultaneous conversion of the GTG start codon to ATG and the incorporation of flanking Bam HI-NdeI and HindIII-PstI sites, with the aid of two primers, S328, 20221 TTGGATCCATA TGCTAGAAGAA TACCGTAAGCACGTAGCTG $_{20261}$, and S329, 23142 TTCTGCAGAAGCTTGTTCCACTTCATCAAGCAAGGCC ${ }_{\mathbf{2 3 1 0 6}}$ (numbered according to Fujita et al., 1994, with superscripted mismatches). The PCR reactions contained $200 \mathrm{ng}$ DNA, 100 pmol of each primer and $2 \mathrm{U} p f u$ DNA polymerase. The major amplified product $(2.9 \mathrm{~kb})$ was purified and cloned as a BamHI-PstI fragment into pUC119. Transformants were screened by sequencing single-stranded phagemid DNA from the universal priming site using the dideoxy chain-termination method. The $2.9 \mathrm{~kb}$ acnB coding region was then subcloned downstream of the IPTG-inducible T7 promoter in pET21a (Novagen), as an NdeI-HindIII fragment from a representative phagemid (pGS782), to generate the expression plasmid pGS783.

Microbiological methods. The routine complex medium was single-strength $\mathrm{L}$ broth (unless stated otherwise) and a rich malate medium was used for specific purposes (Prodromou et al., 1991). A citrate-free minimal medium (Cole \& Guest, 1980) was used with glucose $(11 \mathrm{mM})$ as carbon source and supplements of thiamine hydrochloride $\left(5 \mu \mathrm{g} \mathrm{ml}^{-1}\right)$ and iron citrate $(16 \mu \mathrm{M})$ or citric acid $(0.2 \%, \mathrm{w} / \mathrm{v})$. Cultures were grown aerobically at $37^{\circ} \mathrm{C}$, with ampicillin $\left(100\right.$ or $\left.200 \mu \mathrm{g} \mathrm{ml}^{-1}\right)$ or kanamycin $\left(20 \mu \mathrm{g} \mathrm{ml}^{-1}\right)$ when necessary. For enzyme assays with small-scale cultures $(1.5 \mathrm{ml})$, the bacteria were resuspended in $600 \mu \mathrm{l}$ Tris/citrate buffer $(20 \mathrm{mM}, \mathrm{pH} 8.0)$ at $0^{\circ} \mathrm{C}$ and disrupted by two ultrasonic treatments $(10 \mathrm{~s}$ at $10 \mathrm{MHz}$ separated by a $30 \mathrm{~s}$ interval) in two $300 \mu \mathrm{l}$ aliquots, followed by the removal of cell debris by centrifuging (10000 $\mathrm{g}$ for $5 \mathrm{~min}$ ). To stabilize aconitase activity, dithiothreitol $(5 \mathrm{mM}),\left(\mathrm{NH}_{4}\right)_{2} \mathrm{Fe}\left(\mathrm{SO}_{4}\right)_{2}(1 \mathrm{mM})$ and $\mathrm{Tris} / \mathrm{HCl}(50 \mathrm{mM}, \mathrm{pH} 8.0)$ were added to one aliquot prior to disruption and immediate assay, the other aliquot being used for protein estimation.

Analysis of acnB expression in $\lambda$-infected bacteria and phagemid transformants. Aerobic cultures of E. coli JRG2789 were grown to $\mathrm{OD}_{650} 0.4$ in $20 \mathrm{ml} \mathrm{L}$ broth containing $0.2 \%$ maltose and $10 \mathrm{mM} \mathrm{MgSO}_{4}$, and phages (m.o.i. of 3) adsorbed for $15 \mathrm{~min}$ at $37^{\circ} \mathrm{C}$ without shaking. Shaking was then restarted (time zero) and samples $(1.5 \mathrm{ml})$ were pelleted $(15000 \mathrm{~g}$ for $2 \mathrm{~min}$ ) and stored at $-20^{\circ} \mathrm{C}$ prior to analysis. Transformants of E. coli $\mathrm{DH} 1$ and $\mathrm{BL} 21 / \lambda \mathrm{DE} 3$ were grown with shaking at $37^{\circ} \mathrm{C}$ in $50 \mathrm{ml} \mathrm{L}$ broth containing ampicillin $\left(200 \mu \mathrm{g} \mathrm{ml}^{-1}\right)$ and sampled as described above. Expression of $a \mathrm{cnB}$ from pGS783 was induced with IPTG $\left(40 \mu \mathrm{g} \mathrm{ml}^{-1}\right) 2 \mathrm{~h}$ before the cultures were harvested.

Aconitase assay and reactivation. Aconitase was assayed spectrophotometrically at $20^{\circ} \mathrm{C}$ by following the formation of cis-aconitate from isocitrate at $240 \mathrm{~nm}$, using an absorption coefficient of $3.6 \mathrm{mM}^{-1}$ (Kennedy et al., 1983). One unit (U) corresponds to $1 \mu \mathrm{mol}$ cis-aconitate formed $\mathrm{min}^{-1}$. Protein concentrations were determined by the Bio-Rad micro-assay procedure. Where stated, aconitase was reactivated by incubating samples with dithiothreitol $(5 \mathrm{mM}),\left(\mathrm{NH}_{4}\right)_{2} \mathrm{Fe}\left(\mathrm{SO}_{4}\right)_{2}$ $(1 \mathrm{mM})$ and Tris/ $\mathrm{HCl},(50 \mathrm{mM}, \mathrm{pH} 8.0)$ for $20 \mathrm{~min}$ at $20^{\circ} \mathrm{C}$. Staining for aconitase activity in non-denaturing polyacrylamide gels was performed by coupling the conversion of cis-aconitate to isocitrate to a colorimetric test for isocitrate dehydrogenase (Prodromou et al., 1991).

Purification of AcnB from an unamplified source, JRG2789. AcnB was purified from JRG2789 (acn $A:$ kan $^{\mathbf{R}}$ ) grown with vigorous aeration at $37^{\circ} \mathrm{C}$ for $7 \mathrm{~h}$ in five 21 flasks, each containing $400 \mathrm{ml}$ double-strength $\mathrm{L}$ broth inoculated to give a starting $\mathrm{OD}_{650} 0 \cdot 1$. The bacteria were harvested $(4000 \mathrm{~g}$ for $30 \mathrm{~min})$ and resuspended $\left(0.5 \mathrm{~g}\right.$ wet $\left.\mathrm{wt} \mathrm{ml}^{-1}\right)$ in MES/Mg buffer (10 mM MES/KOH, pH 6.0 , with $5 \mathrm{mM} \mathrm{MgCl}_{2}$ ) before disruption by three passes through a French pressure cell (15000 p.s.i., $103.5 \mathrm{kPa}$ ). Extracts were clarified by centrifuging $(25000 \mathrm{~g}$ for $30 \mathrm{~min}$ and $180000 \mathrm{~g}$ for $2 \mathrm{~h}$ ). All steps were performed at $4{ }^{\circ} \mathrm{C}$. The cell extracts were fractionated with $\left(\mathrm{NH}_{4}\right)_{2} \mathrm{SO}_{4}$ at $45-65 \%$ saturation, the pellets $(15000 \mathrm{~g}$ for $30 \mathrm{~min})$ being solubilized in $10 \mathrm{ml}$ Tris/citrate buffer $(20 \mathrm{mM}$ Tris/citrate, $\mathrm{pH} \mathrm{8.0)}$ containing $0.25 \mathrm{M}\left(\mathrm{NH}_{4}\right)_{2} \mathrm{SO}_{4}$. This was loaded on a Phenyl Sepharose CL-4B column $(5 \times 10 \mathrm{~cm})$ equilibrated with Tris/citrate buffer containing $0.25 \mathrm{M}$ $\left(\mathrm{NH}_{4}\right)_{2} \mathrm{SO}_{4}$, washed with $200 \mathrm{ml}$ of the same buffer, and eluted with a $600 \mathrm{ml}$ linear gradient of $0.25-0.00 \mathrm{M}\left(\mathrm{NH}_{4}\right)_{2} \mathrm{SO}_{4}$ in 


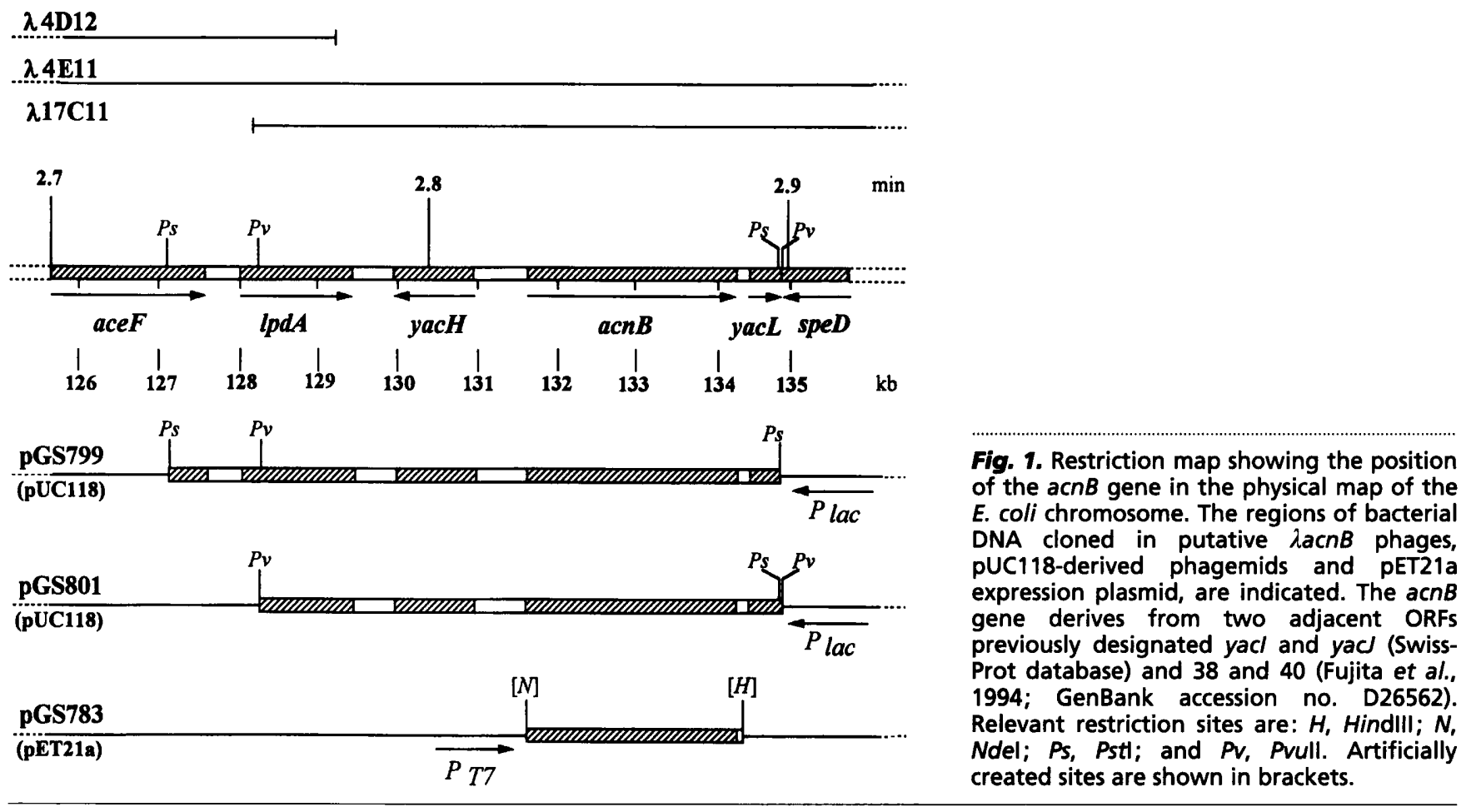

Tris/citrate buffer followed by buffer alone, at a flow rate of $5 \mathrm{ml} \mathrm{min}{ }^{-1}$. Fractions $(15 \mathrm{ml})$ containing aconitase activity eluted $840 \mathrm{ml}$ after applying the gradient. These fractions were pooled and loaded on a Procion Green HE4BD dye affinity column $(2 \times 30 \mathrm{~cm})$ equilibrated with $\mathrm{MES} / \mathrm{Mg}$ buffer, washed with $50 \mathrm{ml} \mathrm{MES} / \mathrm{Mg}$ buffer, and eluted with an $800 \mathrm{ml}$ linear gradient of $0-100 \mathrm{mM}$ citrate in MES/ $\mathrm{Mg}$ buffer at a flow rate of $2 \mathrm{ml} \mathrm{min}^{-1}$. AcnB activity emerged at a citrate concentration of $35 \mathrm{mM}$.

Purification of AcnB from a genetically amplified source, JRG3171. Inocula developed from a freshly prepared pGS801 transformant of DH1 (JRG3171) were used to grow doublestrength $\mathrm{L}$ broth cultures $(5 \times 400 \mathrm{ml})$ with iron citrate $(50 \mu \mathrm{M})$ and ampicillin $\left(200 \mu \mathrm{g} \mathrm{ml}^{-1}\right)$ for $15 \mathrm{~h}$ from a starting $\mathrm{OD}_{650} 0 \cdot 05$, prior to harvesting and extraction, as above. The pellets from $\left(\mathrm{NH}_{4}\right)_{2} \mathrm{SO}_{4}$ fractionation (45-65\% saturation) were combined in $15 \mathrm{ml} \mathrm{MES} / \mathrm{Mg}$ buffer, desalted by ultrafiltration in a Centriprep concentrator $\left(M_{\mathrm{r}} 30000\right.$ cut-off) and then fractionated on a Procion Green HE4BD dye affinity column $(5 \times 10 \mathrm{~cm})$ previously equilibrated with $\mathrm{MES} / \mathrm{Mg}$ buffer, washed with $200 \mathrm{ml}$ of the same buffer, and eluted at $5 \mathrm{ml} \mathrm{min}-1$ with a $2000 \mathrm{ml}$ linear gradient of $0-100 \mathrm{mM}$ citrate in $\mathrm{MES} / \mathrm{Mg}$ buffer. The active fractions eluted at $23 \mathrm{mM}$ citrate, were pooled, desalted and concentrated to $25 \mathrm{ml}$ by ultrafiltration before loading on a Procion Blue HERD dye affinity column $(2.7 \times 30 \mathrm{~cm})$ equilibrated with $\mathrm{MES} / \mathrm{Mg}$ buffer. After washing with $200 \mathrm{ml} \mathrm{MES} / \mathrm{Mg}$ buffer, aconitase activity was eluted at $2 \mathrm{ml} \mathrm{min}{ }^{-1}$ with a $1000 \mathrm{ml}$ linear gradient of $0-100 \mathrm{mM}$ citrate in $\mathrm{MES} / \mathrm{Mg}$ buffer. The $\mathrm{AcnB}$ activity eluted at a citrate concentration of $38 \mathrm{mM}$.

PAGE, $\boldsymbol{M}_{\mathbf{r}}$ determination and $\mathrm{N}$-terminal amino acid sequence analysis. PAGE was according to the method of Laemmli (1970) using denaturing conditions $(0.1 \% \mathrm{SDS}$ in all buffers and $15 \%, \mathrm{w} / \mathrm{v}$, acrylamide) or non-denaturing conditions (no SDS and $10 \%$ acrylamide). A Bioprofil image analyser (Vilber-
Lourmat) was used for densitometric quantification of Coomassie-Blue-stained acrylamide gels. The subunit and native $M_{\mathrm{r}}$ of AcnB were deduced from SDS-PAGE mobilities and by gel filtration through a Sephacryl S200 HR column $(30 \times 2 \mathrm{~cm})$ equilibrated and eluted with $10 \mathrm{mM} \mathrm{MES} / \mathrm{KOH}(\mathrm{pH} 6.0$ ) containing $100 \mathrm{mM} \mathrm{MgCl}$ at $0.5 \mathrm{ml} \mathrm{min}^{-1}$. The column was calibrated with standard proteins $\left(M_{\mathrm{r}}\right): \beta$-amylase (200000), alcohol dehydrogenase (150000), BSA (66000), carbonic anhydrase (29000), cytochrome $c(12400)$. The $\mathrm{N}$-terminal amino acid sequences were determined by Edman degradation using an Applied Biosystems protein sequencer with samples of $A c n B$ and other polypeptides from Coomassie-Blue-stained electroblots of SDS-PAGE gels.

Western blotting. Samples fractionated by SDS-PAGE were transferred to nitro-cellulose using a Bio-Rad Transblot Electrophoretic Transfer Cell and the blots were immuno-stained with anti-AcnA serum as the primary antiserum, biotinylated antirabbit antibodies and streptavidin-biotinylated horseradish peroxidase complex, according to the method of Prodromou et al. (1991). Biotinylated size markers were $\left(M_{\mathrm{r}}\right)$ : phosphorylase $b$ (97400), catalase (58100), alcohol dehydrogenase (39800), and carbonic anhydrase (29000).

DNA manipulation and related methods. DNA was prepared and manipulated by standard procedures (Sambrook et al., 1989). The mixed oligonucleotides used in attempts to PCR-amplify and clone $a c n B$ sequences were: S325, ATG(TC)TIGA(GA)GA(GA)TA(TC)(AC)G(ATGC)AA(AG); S326, ${ }^{2555} \mathrm{GG}(\mathrm{GA})$ TT(ATGC)(GC)(TA)(ATGC)G(TA)(GA)TT(ATGC)G(TA)(AG)CA(ATGC)(GC)(AT) ${ }^{2533}$; and $\mathrm{S} 327,{ }^{1756} \mathrm{CC}(\mathrm{ATGC})-$ GG(ATGC)(AT)(CG)(ATGC)GG(ATGC)AT(TC)(TA)(TG)(ATGC)CA(TC)CA(AG)(AG) $\mathrm{T}^{\mathbf{1 7 8 1}}$ (coordinates refer to the acn $A$ gene; Prodromou et al., 1992). Amplified products were either blunt-ended using DNA polymerase (Klenow fragment) or digested with Sau3A for cloning into HincII- or BamHI-digested pUC118, respectively. DNA-directed tran- 
scription-translation was performed with an E. coli S30 extract (Promega) and circular dsDNA. Reaction mixtures contained (in $50 \mu \mathrm{l}): \mathrm{DNA}, 1.5 \mu \mathrm{g}$; $\left.{ }^{35} \mathrm{~S}\right] \mathrm{L}$-methionine, $15 \mu \mathrm{Ci}(555 \mathrm{kBq}$, $12 \mathrm{pmol}$ ); amino acid mixture minus methionine, $0.1 \mathrm{mM}$; and S30 extract plus premix, according to manufacturer's instructions. Radiolabelled polypeptides were fractionated by SDSPAGE and detected autoradiographically.

Materials. Isocitric acid, tetranitroblue tetrazolium, phenazine methosulphate, isocitrate dehydrogenase, biotinylated molecular mass markers and molecular mass markers for gel filtration were obtained from Sigma. Alkaline phosphatase, NADP and T4 DNA ligase were from Boehringer Mannheim. Restriction enzymes and DNA polymerase (Klenow fragment) were pur-

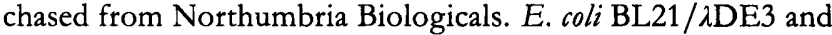
the pET21a expression plasmid were purchased from Novagen. Procion dyes were obtained from Kemtex. Molecular mass markers for SDS-PAGE were from BDH. Centricon 30 concentrators were obtained from Amicon. PCR was performed using $p f u$ DNA polymerase purchased from Stratagene. Radiolabelled $\left[\alpha-{ }^{35} S\right] d A T P$ and $\left[{ }^{35} S\right] L$-methionine, biotinylated antirabbit antibody and streptavidin-biotinylated horseradish peroxidase complex, were obtained from Amersham. Universal primer and Sequenase were purchased from Cambridge BioScience.

\section{RESULTS}

\section{Partial purification and characterization of AcnB from E. coli JRG2789 (acnA:: $\left.\operatorname{kan}^{\mathrm{R}}\right)$}

The second aconitase $(\mathrm{AcnB})$ of E. coli was purified from a genetically engineered acn $A:$ : kan ${ }^{\mathbf{R}}$ mutant (JRG2789) which lacks AcnA (Gruer \& Guest, 1994). Previous studies had indicated that $A \operatorname{cnB}$ is not an abundant enzyme, so different growth media were tested in an attempt to find an enriched source for use as starting material. The maximum specific activities observed throughout late-exponential and early-stationary phases were [U (mg protein $)^{-1}$ in ultrasonic extracts]: L broth $(0.39)$; double-strength $\mathrm{L}$ broth $(0.32)$; rich malate $(0.31)$; glucose minimal $(0 \cdot 10)$; glucose minimal plus iron $(0 \cdot 18)$; and glucose minimal plus citrate $(0 \cdot 14)$. Early-stationaryphase double-strength $\mathrm{L}$ broth cultures were chosen to take advantage of the higher growth yield and the relatively high specific activity.

A typical AcnB purification is summarized in Table 1 and an SDS-PAGE fractionation of samples taken at each stage is shown in Fig. 2(a). Major activity losses occurred during the chromatographic steps, the overall yield $(0 \cdot 3 \%)$ and purification factor $(1 \cdot 6$-fold) being particularly low. However, it is likely that the low specific activities are partly due to irreversible inactivation rather than loss of AcnB protein. Oxidative degradation of the ironsulphur cluster during purification probably generates an inactive but co-purifying apo-protein which lowers the specific activity of the final product.

Although partially purified AcnB contained several polypeptide components, only one $\left(M_{\mathrm{r}} 100000\right)$ was continuously enriched and had a fractionation pattern that correlated with the activity profile in the final stages of purification (Fig. 2a). The same polypeptide was one of three that cross-reacted, albeit weakly, with anti-AcnA serum in Western blotting. Activity staining of partially purified samples of the enzyme after fractionation in nondenaturing polyacrylamide gel (Fig. $2 \mathrm{~b}$, lane 5 ) further showed that the active band contains a polypeptide of $M_{\mathrm{r}}$ 100000 in SDS-PAGE (Fig. 2b, lane 6). In direct comparisons, the mobility of the putative AcnB polypeptide was slightly less than that of the purified AcnA protein $\left(M_{\mathrm{r}} 97500\right)$. A native $M_{\mathrm{r}}$ of $105000( \pm 8000)$ was determined for the AcnB protein by monitoring the

Table 1. Purification of aconitase $B$ from E. coli

AcnB was purified from (a) the unamplified source, JRG2789 and (b) the genetically amplified source, JRG3171 or DH1(pGS801). One unit of activity is defined as the amount required to generate $1 \mu \mathrm{mol}$ cis-aconitate $\min ^{-1}$ at $20^{\circ} \mathrm{C}$. The recorded activities are those obtained after reactivation, and the extent of reactivation is given in parentheses for samples taken at each stage of the purification procedure.

\begin{tabular}{|lccccc|}
\hline $\begin{array}{l}\text { Purification } \\
\text { step }\end{array}$ & $\begin{array}{c}\text { Total activity } \\
\text { units } \\
\text { (reactivation } \\
\text { factor) }\end{array}$ & $\begin{array}{c}\text { Total } \\
\text { protein } \\
\text { (mg) }\end{array}$ & $\begin{array}{c}\text { Specific } \\
\text { activity } \\
{[\mathbf{U}(\mathbf{m g}} \\
\text { protein) }\end{array}$ & $\begin{array}{c}\text { Yield } \\
\text { (\%) }\end{array}$ & $\begin{array}{c}\text { Purification } \\
\text { factor }\end{array}$ \\
\hline JRG2789 & & & & & \\
Cell extract & $240(1 \cdot 0)$ & 900 & $0 \cdot 26$ & 100 & $1 \cdot 0$ \\
$\left(\mathrm{NH}_{4}\right)_{2} \mathrm{SO}_{4}$ ppn & $160(1 \cdot 6)$ & 325 & $0 \cdot 49$ & 67 & $1 \cdot 8$ \\
Phenyl Sepharose CL-4B & $4 \cdot 6(1 \cdot 0)$ & 19 & $0 \cdot 24$ & $1 \cdot 9$ & $0 \cdot 9$ \\
Procion Green HE4BD & $0 \cdot 64(1 \cdot 0)$ & $1 \cdot 5$ & $0 \cdot 43$ & $0 \cdot 3$ & $1 \cdot 6$ \\
JRG3171/DH1(pGS801) $_{\text {Cell extract }}$ & $4300(1 \cdot 0)$ & 700 & $6 \cdot 1$ & 100 & $1 \cdot 0$ \\
NH $\left._{4}\right)_{2} \mathrm{SO}_{4}$ ppn & $2400(1 \cdot 0)$ & 490 & $4 \cdot 9$ & 56 & $0 \cdot 8$ \\
Procion Green HE4BD $_{\text {Procion Blue HERD }}^{1330(83)}$ & $350(21)$ & 60 & $22 \cdot 2$ & 30 & $3 \cdot 6$ \\
\hline
\end{tabular}


(a)

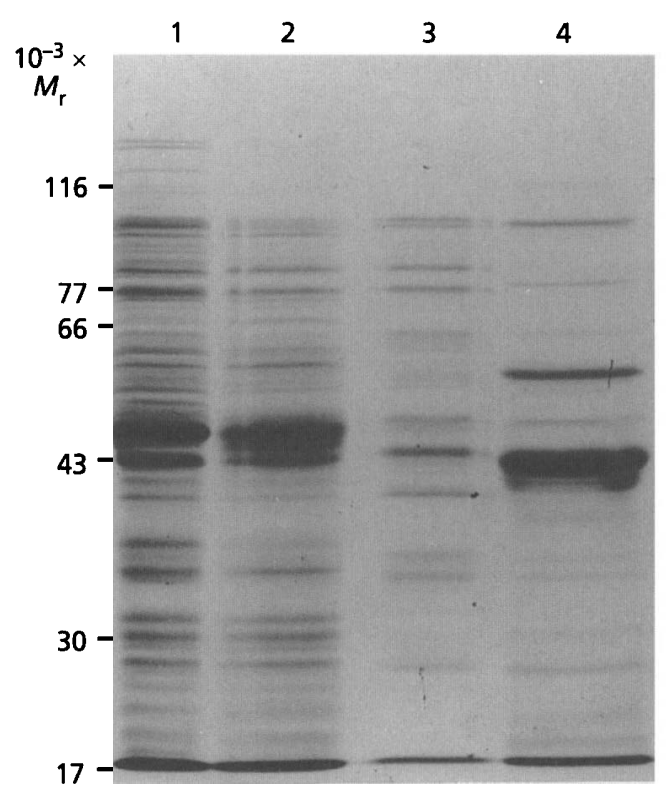

(b)

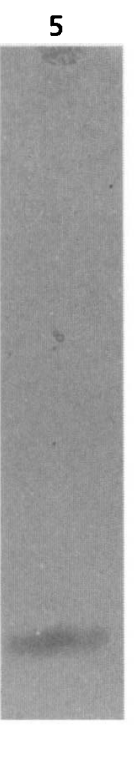

(c)

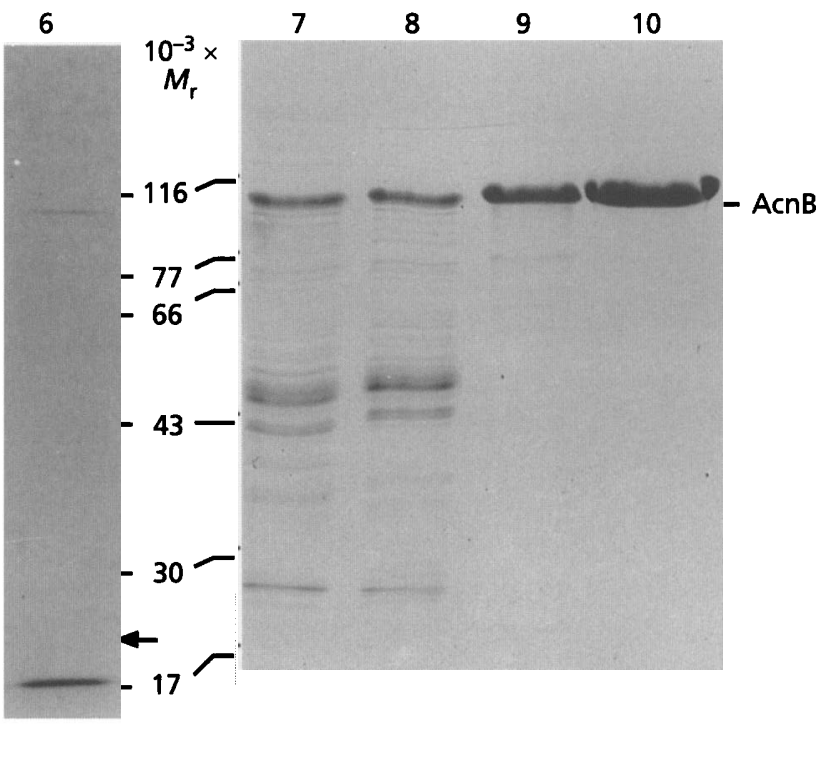

Fig. 2. Purification and activity staining of AcnB. (a) Purification of AcnB from an unenriched source, JRG2789. Coomassie-Blue-stained SDS-PAGE (15\% gel) showing samples of active fractions at different stages. Lanes: 1 , cell-free extract; 2, ammonium sulphate precipitate; 3, Phenyl Sepharose; 4, Procion Green HE4BD. (b) Activity staining of AcnB. Lanes: 5, activity-stained gel containing the lane 4 sample of partially purified AcnB fractionated in non-denaturing PAGE (10\% gel); lane 6, SDS-PAGE (15\% gel)-fractionated and Coomassie-Blue-stained gel containing the enzymically active band (arrowed) excised from lane 5. (c) Purification of AcnB from a genetically enriched source JRG3171, DH1(pGS801). Coomassie-Blue-stained SDS-PAGE ( $15 \%$ gel) with active fractions from cell-free extract (lane 7 ), ammonium sulphate precipitate (lane 8), Procion Green HE4BD (lane 9), Procion Blue HERD (lane 10).

elution of enzyme activity in quantitative gel filtration studies.

Several preparations of AcnB purified by Procion Green chromatography (Table 1; Fig. 2a) were fractionated by SDS-PAGE to determine the $\mathrm{N}$-terminal amino acid sequence of the polypeptide tentatively identified as AcnB by activity staining and by Western Blotting. In all cases the $M_{\mathrm{r}} 100000$ polypeptide had the following $\mathrm{N}$-terminal sequence: MLEEYRKHxAE, where $\mathrm{x}$ denotes an unidentified residue. Two other immunopositive polypeptides of $M_{\mathrm{r}} 46000$ and 35000 in partially purified AcnB had N-terminal sequences that were identical to isocitrate dehydrogenase over 24 residues, indicating that they correspond to isocitrate dehydrogenase and a C-terminally degraded form, respectively. Their appearance suggests that the protein originally used to raise the AcnA antiserum was contaminated with isocitrate dehydrogenase. Indeed it would seem that isocitrate dehydrogenase co-purifies to some extent with both AcnA and AcnB.

\section{Identification of the acnB gene}

Preliminary attempts to clone the acn $B$ gene by a PCR amplification strategy using DNA from the $\operatorname{acn} A:: k a n^{\mathbf{R}}$ mutant (JRG2789) and mixed oligonucleotide primers encoding the $\mathrm{N}$-terminus of $\mathrm{AcnB}$ (S325) and two highly conserved internal regions of the aconitase-IPMI family that are deleted in JRG2789 (S326 and S327), failed. None of the amplified products resembled ain $A$ sequences. With hindsight it is apparent that there is insufficient similarity between AcnA and AcnB (even in the most conserved regions) for this approach to have been successful (e.g. there are identical residues at only three out of eight and five out of nine positions in the chosen internal regions).

Subsequent database searches revealed that the $\mathrm{N}$-terminal sequence of the putative $A \mathrm{cnB}$ protein is encoded by an internal segment of a 408 bp unidentified ORF (yacI in the Swiss-Prot database; 38 in Fujita et al., 1994, GenBank D26562). This short segment of DNA was located immediately upstream of a 2319 bp ORF (yacJ in the Swiss-Prot database; 40 in Fujita et al., 1994) part of which had been recognized as encoding a product that is $23 \%$ identical to a fungal isopropylmalate dehydratase (Fujita et al., 1994). It was realized that if the two ORFs (yacI and yacJ) were fused by a frame-shifting single base-pair insertion in the upstream sequence, the resultant reading frame would encode a polypeptide having the same Nterminal sequence and approximately the same $M_{\mathrm{r}}(93500)$ as AcnB (Berlyn et al., 1996). The putative yacIJ gene, hereinafter designated $a \mathrm{cn} \mathrm{B}$, is located at $2.85 \mathrm{~min}$ $(131.6 \mathrm{~kb})$ in the physical map of the E. coli chromosome (Fig. 1) and it is flanked by two further ORFs ( $y a c H$ and yacL), which are in turn situated between the $l p d A$ and $s p e D$ genes. 
(a)
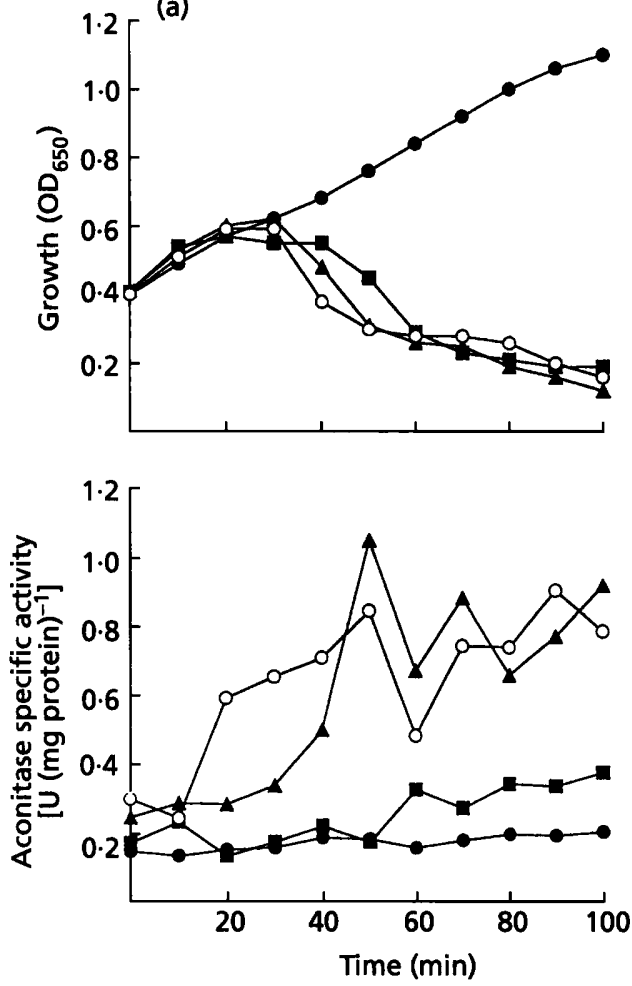

(b)
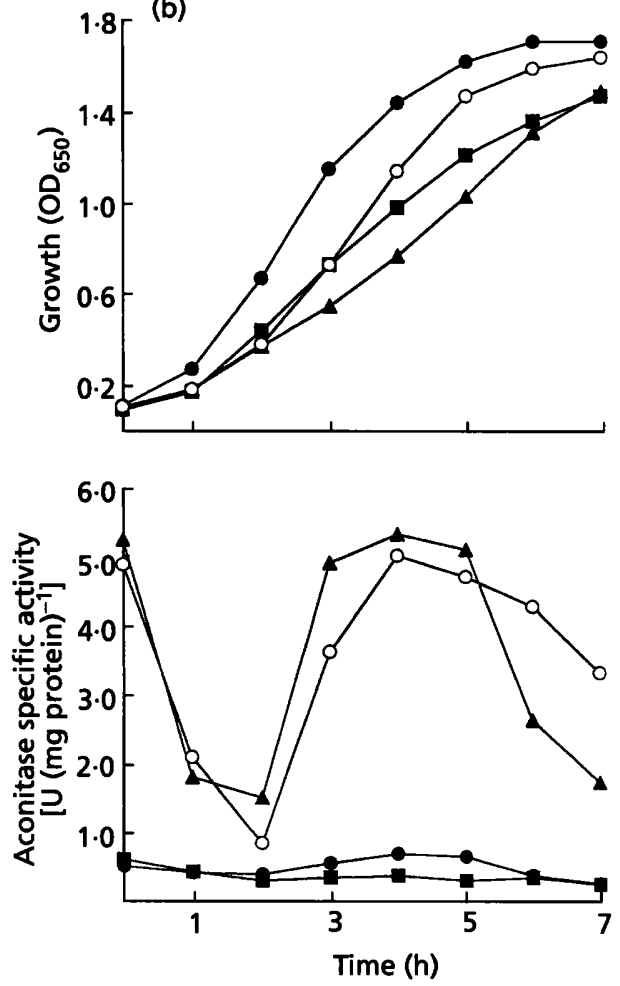

Fig. 3. Aconitase activities of $\lambda a c n B$-infected and phagemid-containing $E$. coli. (a) The aconitase specific activities for cultures of JRG2789 infected with $\lambda E M B L 4$-derivatives $(m .0 . i .=3$ ) are shown below the corresponding growth curves. Uninfected; $\boldsymbol{Q}, \lambda 4 \mathrm{D} 12 ; \Delta, \lambda 4 \mathrm{E} 11 ; 0, \lambda 17 \mathrm{C11}$. (b) The aconitase specific activities of transformants of $E$. coli $\mathrm{DH} 1 \mathrm{grown}$ in $\mathrm{L}$ broth plus ampicillin $\left(200 \mu \mathrm{g} \mathrm{ml}^{-1}\right)$ are shown below the growth curves. $\bigcirc$, Untransformed; $\mathbf{\square}, \mathrm{pUC118}$ (vector); $\Delta$, pGS799; O. pGS801.

\section{Studies with putative $\lambda$ acnB phages and characterization of phagemids containing the acnB gene}

The first direct evidence that the $a{ }^{\prime} n B$ gene is located in the yacIJ region was obtained by infecting JRG2789 with selected phages from the $\lambda-E$. coli W3110 gene library (Kohara et al., 1987). Aconitase activity was significantly and reproducibly increased about four- to sixfold after infection with $\lambda 4 \mathrm{E} 11$ and $\lambda 17 \mathrm{C} 11$ which contain the yacIJ region (Fig. 1), but not with a phage ( $\lambda 4$ D12) that lacks this region (Fig. 3a). There was also a reproducible correlation between the orientation of $a c n B$ (yacIJ) in the phage genome and the early or late increase in aconitase activity (Fig. 3a). Thus, activity increased 20 min earlier with $\lambda 17 \mathrm{C} 11$, where $a c n B$ should be transcribed from the early phage promoter $\left(\lambda \mathrm{P}_{\mathbf{L}}\right)$, than with $\lambda 4 \mathrm{E} 11$, where $a c n B$ has the same polarity as the late promoter $\left(\lambda \mathrm{P}^{\prime}{ }_{\mathbf{R}}\right)$.

Two derivatives of pUC118 containing the acnB (yacIJ) gene of $\lambda 4 \mathrm{E} 11$ were constructed by subcloning the $7 \cdot 4 \mathrm{~kb}$ Pst I fragment containing the $l p d A-y a c H-a c n B$ region to generate pGS799, and the $6.5 \mathrm{~kb}$ PvuII fragment containing the $y a c H-a c n B-y a c L$ region to generate pGS801 (Fig. 1). In each case, the aconitase specific activities of the corresponding DH1 transformants were up to 10 -fold higher than those of the vector control during earlystationary phase (Fig. 3b). SDS-PAGE analysis clearly showed that a polypeptide of the size expected for AcnB $\left(M_{r} 100000\right)$ is enriched in cell-free extracts of DH1(pGS799) and DH1(pGS801) prepared from lateexponential-phase cultures (Fig. 4a). Another polypeptide corresponding to the $l p d A$ gene product, lipoamide dehydrogenase $\left(M_{\mathrm{r}} 55000\right)$, was enriched in DH1(pGS799) but not in DH1(pGS801) which lacks the complete lpd $A$ gene (Fig. 4a). No enriched products corresponding to the yacH or yacL genes were detected. Densitometric analyses of Coomassie-Blue-stained gels indicated that the putative AcnB protein amounts to $30 \%$ and $50 \%$ of soluble cell protein in the pGS799 and pGS801 transformants compared with $<1 \%$ in the untransformed host, DH1. The degree of amplification is greater than might be expected from the increase in AcnB activity, suggesting that a large proportion of the enzyme accumulates in an inactive state. Attempts to reactivate this protein were unsuccessful.

In parallel in vitro transcription-translation experiments, pGS799 and pGS801 each directed the synthesis of three major labelled polypeptides in addition to those produced in control reactions (Fig. 4b). The $a c n B$ product $\left(M_{\mathrm{r}}\right.$ $100000)$ and putative yacH product $\left(M_{\mathrm{r}} 41000\right)$ were common to both, whereas products corresponding to the lpd $A\left(M_{\mathrm{r}} 55000\right)$ and yacL $\left(M_{\mathrm{r}} 11000\right)$ genes were associated only with pGS799 and pGS801, respectively. 
(a)

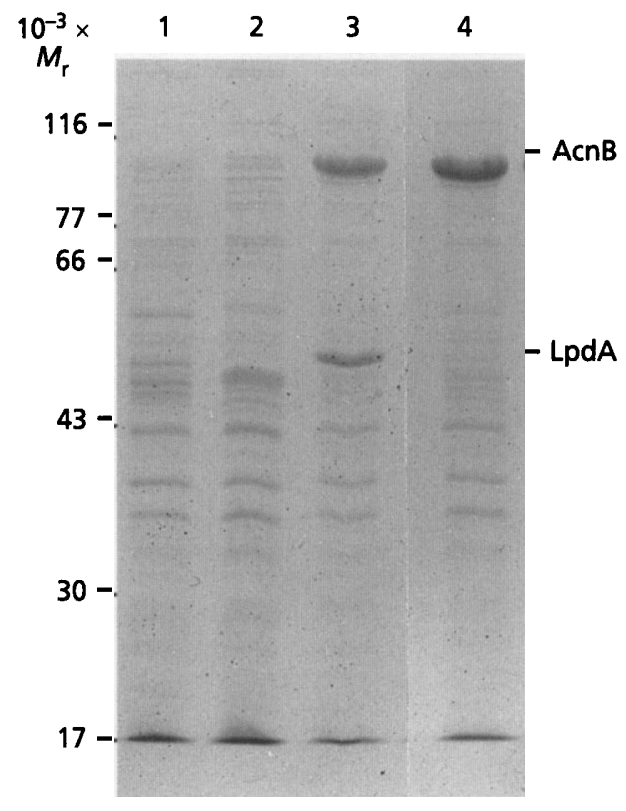

(b)

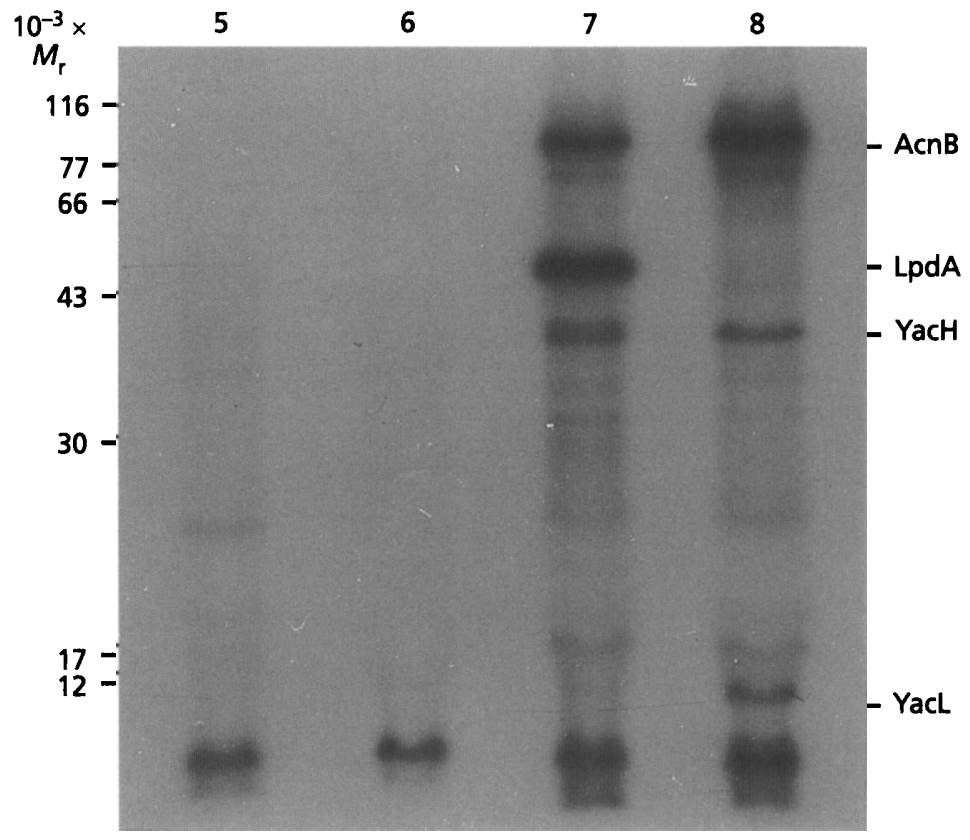

Fig. 4. Analysis of polypeptides expressed by the acnB-containing phagemids, pGS799 and pGS801. (a) Coomassie-Bluestained SDS-PAGE $(15 \% \mathrm{gel})$ containing cell-free extracts of stationary-phase cultures of $E$. coli DH1 and transformed derivatives. Lanes: 1, untransformed; 2, DH1(pUC118); 3, DH1(pGS799); 4, DH1(pGS801). (b) Autoradiograph of fractionated ${ }^{35} \mathrm{~S}$-labelled polypeptides expressed from phagemid DNA in in vitro transcription-translation experiments. Lanes: 5, no DNA; 6, pUC118 (vector control); 7, pGS799; 8, pGS801. Relevant labelled products and the positions of $M_{\mathrm{r}}$ markers are indicated.

The minor labelled products probably represent in vitro artefacts or degraded forms of the major polypeptides.

\section{Aconitase amplification from the acnB coding region}

The above observations are consistent with the proposal that $\mathrm{AcnB}$ is encoded by the combined yacIJ reading frame. To confirm this possibility, single-stranded pGS782 phagemid DNA was used to sequence a $393 \mathrm{bp}$ DNA segment extending from the proposed translational start of acnB in yacI (coordinate 20231; Fujita et al., 1994, GenBank D26562) up to a point $117 \mathrm{bp}$ within the downstream yacJ reading frame (coordinate 20620). A single $\mathrm{C}$ insertion was detected immediately after coordinate 20455, indicating that the yacI reading frame is indeed contiguous with yacJ. Relative to the previous sequence, an extra alanine codon (CGC, coordinates 20344-20346) and a silent $T$ for $C$ replacement (coordinate 20383), were also detected within the sequenced region (GenBank accession no. U41560, for revised sequence). The proposed $a c n B$ coding region starts with a GTG (formyl-methionine) codon preceded by a well-placed RBS (GAGCGAGGAGAACCGTCGTG). It extends for a total of 865 amino acid codons until terminated by a UAA stop codon (coordinate 22826-22828). The codon usage is typical of an E. coli coding region. Furthermore, the low proportion of modulatory codons $(0.58 \%)$ combined with a strong preference for optimum energy codons $(60.6 \%)$ suggests that $a \mathrm{cn} B$ is strongly expressed compared with $\operatorname{acn} A$, where the corresponding values
(3.8 and $44.6 \%)$ are indicative of weak to moderate expression (Grosjean \& Fiers, 1982; Prodromou et al., 1992). The size of the predicted gene product $\left(M_{\mathrm{r}} 93500\right)$ is slightly less than that estimated from the electrophoretic mobility of AcnB. The coding region is flanked by a $593 \mathrm{bp}$ upstream non-coding region containing several possible $a c n B$ and $y a c H$ promoters (Fig. 1) and by a 221 bp downstream region encoding a potential Rho-independent terminator, i.e. a GC-rich region of hyphenated dyad symmetry followed by a $\mathrm{T}(\mathrm{U})$-rich sequence, ATGCCCGG $^{\mathrm{T}}$ GAAT $^{\mathrm{GAG}}$ ATTCCCGGGCAT $^{\text {TTTTTTATTT }}$ (coordinates 22861-22898; the non-complementary base in the GC-rich stem $\left({ }^{\mathrm{T}}\right)$, the loop $\left({ }^{\mathrm{GAG}}\right)$, and all of the bases in the T-rich sequence, are superscripted).

The gene was conclusively identified as the $a c n B$ gene by subcloning the PCR-amplified coding region downstream of the IPTG-regulated T7 promoter of pET21a, and showing that relative to vector-containing controls, aconitase activity could be raised by factors of 5- to 27fold in JRG3099, a transformant of BL21/ $\lambda$ DE3 containing the corresponding expression plasmid (pGS783, see Methods). The wide range of specific activities [2-11 $\mathrm{U}$ (mg protein $)^{-1}$ ] observed after inducing cultures in mid-exponential phase $\left(\mathrm{OD}_{650} 0.7\right)$, sharply contrasted with the almost uniform amplification of $A \mathrm{cnB}$ protein to $48 \%$ of soluble protein in Coomassie-Blue-stained SDSPAGE fractionated samples (not shown). As with DH1(pGS799) and DH1(pGS801), it would appear that much of the amplified AcnB protein accumulates in an 
inactive form. The proportion of inactive AcnB protein was extremely variable and attempts to reactivate samples to a uniformly high activity failed.

It can be calculated that an iron concentration of $8.5 \mu \mathrm{M}$ would be needed to provide BL21/ 2 DE3(pGS783) with sufficient iron for the synthesis of active $A \mathrm{cnB}$ at $48 \%$ of soluble protein. A deficiency in iron might thus limit the synthesis of active $A c n B$ because $L$ broth contains only $17 \mu \mathrm{M}$ iron (S. C. Andrews \& A. J. Hudson, personal communication). After growth and induction in $\mathrm{L}$ broth supplemented with $50 \mu \mathrm{M}$ iron citrate, the range of $\mathrm{AcnB}$ specific activities increased about two- to fourfold [to 3.5-41 U (mg protein $)^{-1}$, which is 9-120-fold higher than the vector-containing control]. This suggests that for equivalent amounts of protein, a greater proportion of AcnB produced in BL21/ $\lambda \mathrm{DE} 3$ ( $\mathrm{pGS783)}$ is in a reactivatable form when the iron concentration in the medium is increased. The specific activities were still very variable and again could not be reactivated to a uniform level. Nevertheless, iron citrate $(50 \mu \mathrm{M})$ was added thereafter to the medium used for the amplification of AcnB. Raising the iron concentration to $100 \mu \mathrm{M}$ produced no further increase in $A c n B$ content or specific activity. Likewise, no increase in $\mathrm{AcnB}$ activity was observed when extra iron was added to the growth medium of DH1(pGS799) or DH1(pGS801) cultures, further indicating that most of the inactive protein is not in the reactivatable [3Fe-4S] form. The reason why DH1(pGS799) and DH1(pGS801) produced greater proportions of unreactivatable $A \mathrm{cnB}$ than BL21/ $\lambda$ DE3(pGS783) is not known, but it may reflect differences in iron-sulphur centre assembly or stability under different culture conditions.

\section{Purification of AcnB from E. coli JRG3171, DH1(pGS801)}

E. coli JRG3171, a pGS801 transformant of DH1 containing multiple copies of the acnB gene, was chosen as the source for purifying $A \mathrm{cn} B$ because it gave consistently high specific activities and because $A c n B$ was the only protein that was significantly overproduced in this strain. A typical purification is shown in Table 1 and an SDSPAGE fractionation of samples taken at each step is shown in Fig. 2(c). The AcnB protein was purified to $\geqslant 98 \%$ homogeneity with an overall yield of $8 \%$ and a purification factor of 6.2 -fold. Unlike the material from the unenriched source, the enzyme eluted at the final stage could be reactivated some 21 -fold to give a final specific activity of $38 \mathrm{U}(\mathrm{mg} \text { protein })^{-1}$. The discrepancy apparent from the need for a sixfold enrichment to purify a protein that is already $50 \%$ pure in the starting material again suggests that there are different relative proportions of active, reversibly inactive and irreversibly inactive enzyme in different samples.

\section{DISCUSSION}

Despite its inherent instability, the second E. coli aconitase (AcnB) was partially purified from an acn $A$ mutant in extremely low but sufficient yield to permit identification and $\mathrm{N}$-terminal sequence analysis of the polypeptide and subsequent isolation of the $a c_{n} B$ gene. During purification no evidence was obtained for the presence of further aconitase activities in E. coli, but their existence cannot be excluded, especially as this organism is known to express three differentially regulated fumarases (Guest, 1992). Whether there are more than two aconitases is now being addressed by constructing an acn $A$ acnB double mutant. Like other aconitases, AcnB is monomeric. Its $M_{\mathrm{r}}$ (93500-105000 by different methods) most closely resembles those of AcnA $\left(M_{\mathrm{r}} 97500\right)$ and the IRP $\left(M_{\mathrm{r}}\right.$ 98000), which are significantly larger than the mammalian and yeast mitochondrial enzymes $\left(M_{\mathrm{r}} 79000-83000\right)$, but smaller than the Bacillus subtilis and Salmonella typhimurium enzymes $\left(M_{\mathrm{r}} 120000\right.$ approx.).

Overproduction to $50 \%$ of soluble cell protein allowed $A c n B$ to be purified essentially to homogeneity. The specific activity of pure reactivated AcnB [38 U (mg protein $)^{-1}$ ] is somewhat lower than that of reactivated AcnA [59 U (mg protein $)^{-1}$ ] purified from a comparably amplified source under similar conditions (Bennett $e t$ al., 1995). However, such comparisons must be interpreted with care because a significant proportion of both the amplified-crude and purified $A c n A$ and $A c n B$ proteins could not be reactivated by incubating with ferrous ions under reducing conditions (Bennett et al., 1995; M. J. Gruer \& J. R. Guest, unpublished observations). Much of the $A \mathrm{cnB}$ protein would thus seem to be produced in an irreversibly inactivated apo-form, in addition to being irreversibly degraded during purification. It has been proposed that the iron released in the conversion of [4Fe-4S] to [3Fe-4S] clusters under aerobic conditions may generate hydroxyl radicals that inflict irreversible enzyme damage, because a smaller proportion of $A c n A$ is irreversibly degraded after anaerobic purification (Bennett et al., 1995). It will be interesting to determine whether the NifS protein, which catalyses the formation of ironsulphur clusters using cysteine-derived enzyme-bound persulphide as the sulphide donor, will reactivate AcnB, as has been observed for apo-nitrogenase and FNR (Zheng \& Dean, 1994; Khoroshilova et al., 1995).

The acnB gene is flanked by two unidentified ORFs ( $y a c H$ and $y a c L$ ) which in turn are located between the pyruvate dehydrogenase operon ( $p d b R-a c e E F-l p d A)$ and the $S$ adenosylmethionine decarboxylase gene, speD (Fig. 1). No clues about the functions of $y a c H$ and $y a c L$ could be gleaned from database searches for potential homologues. However, their locations suggest that they may have functions connected with the CAC and this possibility is being investigated.

Computer-based sequence comparisons using DIAGON (Staden, 1982) failed to reveal any sustained similarities between AcnB and AcnA or other members of the Acn/IRP/IPMI family. However, several conserved active-site residues and motifs were detected in $A \operatorname{cn} B$ by visual inspection, but these could only be aligned with their counterparts in $A c n A$, by cyclically permuting the domain organization from 1-2-3-4 in AcnA to 4-1-2-3 in AcnB. This rearrangement is illustrated in Fig. 5 where the domain corresponding to the $\mathrm{C}$-terminal domain in 


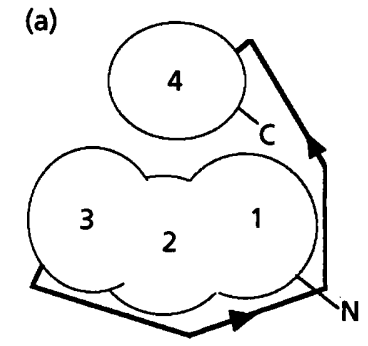

$123\llcorner 4$
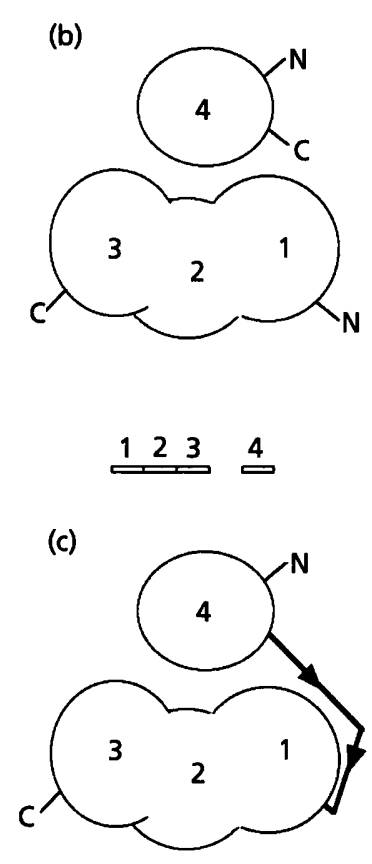

$4 L 123$

Fig. 5. Structural relationships in the aconitase, IRP and IPMI family of proteins. The domain organizations represent (a) $E$. coli AcnA and all known aconitases except $E$. coli AcnB, IRP and fungal IPMI; (b) bacterial IPMI; and (c) E. coli AcnB. The N- and $C$-termini of individual proteins are indicated and the polarities of the linker regions (heavy lines) are marked by arrows.

AcnA (domain 4) becomes the $\mathrm{N}$-terminal domain in AcnB. The long linker connecting domains 3 and 4 in $A \operatorname{cn} A$ is absent in the arrangement proposed for $A c n B$, where domain 4 is joined directly to the rest of the molecule via domain 1 (Fig. 5). Members of the Acn/ IRP/IPMI family thus exhibit three distinct ways of achieving similar overall structural conformations, domain 4 being situated either at the $\mathrm{N}$ - or C-termini of single polypeptides, or provided by a completely independent polypeptide (Fig. 5). The present arrangements in $A \operatorname{cn} A$ and $A \mathrm{cn} B$ may have arisen by the fusion of two ancestral genes which had previously come together in different relative orders, one of which corresponds to the current bacterial IPMI (leuCD) situation. An alternative evolutionary route for generating a cyclically permuted coding region might have involved tandem duplication of the ancestral gene(s) followed by the deletion of flanking DNA. The relationship between either AcnA or AcnB and the two-subunit bacterial IPMI resembles the relationship between the dimeric iron-sulphur containing fumarases (FumA or FumB) and the tetrameric L-tartrate dehydratase ( $\mathrm{Ttd}$ ), where the amino acid sequence of each fumarase corresponds to the combined TtdA and TtdB sequence, the overall sequence identity being $23-25 \%$ (Reaney et al., 1993).

A multiple amino acid sequence alignment was made by repositioning different $\mathrm{C}$-terminal segments of the $\mathrm{AcnB}$ sequence at the $\mathrm{N}$-terminal end and making computerbased comparisons with selected Acn, IRP and IPMI sequences (Fig. 6). A computerized version of a previous multiple alignment (Prodromou et al., 1992) was first constructed using PILEUP (Higgins \& Sharp, 1989) and LINEUP (Gribskov et al., 1990), and was then optimally aligned with AcnB using PROFILEMAKE and PROFILEGAP (Schwartz \& Dayhoff, 1979). The alignment was ultimately refined by inspection. Some 17 of the 20 active-site residues assigned in porcine mitochondrial aconitase are conserved in $A c n B$, including the three cysteine residues involved in ligand binding to the iron-sulphur centre (Fig. 6). Most of the secondary structural elements in porcine aconitase appear to be conserved in $A \mathrm{cnB}$ and the insertion-deletions are located in superficial loops and turns. The main differences concern the absence of a sequence corresponding to the long interdomain linker in $A \mathrm{cnB}$, the absence of three helical segments from the $\mathrm{N}$ terminal region of domain 1 , and the presence of 120 unaligned $\mathrm{N}$-terminal residues connected to domain 4 in AcnB (Fig. 6). The overall amino acid sequence identities between AcnB and porcine aconitase $(15 \%), A \operatorname{cn} A$ $(17 \%)$, IRP $(17 \%)$, and the IPMI of Mucor circinelloides $(18 \%)$ and $S$. typhimurium (15\%), were deduced using DISTANCES (University of Wisconsin Genetics Group). The corresponding relationships with $A c n A$ are: porcine aconitase (29\%); AcnB (17\%); IRP (53\%); and the IPMI of $M$. circinelloides $(21 \%)$ and S. typhimurium $(21 \%)$, indicating that $A \operatorname{cnB}$ is only distantly related to other members of the family.

Possible reasons for the duplication of metabolic genes and enzymes including citrate synthase, succinate dehydrogenase and fumarase, have been discussed previously (Gruer \& Guest, 1994; Guest, 1995). AcnA and AcnB appear not to have mutually exclusive functions because AcnB successfully complements the AcnA deficiency in the acn $A:: k a n^{\mathrm{R}}$ mutant. It will be interesting to ascertain whether the converse is true in an acnB mutant. The codon preferences suggest that the $a c n B$ gene is more strongly expressed than acn $A$. It seems likely that $a c n B$ will exhibit a different pattern of regulatory responses to $\operatorname{acn} A$, which is subject to ArcA- and FNR-mediated repression and CRP-, SoxRS-, RpoS-, and Fur-mediated activation, and it has been suggested that $A \mathrm{cnB}$ might be preferentially used in the glyoxylate cycle (Gruer \& Guest, 1994; M. J. Gruer \& J. R. Guest, unpublished 


$\begin{array}{llr}\text { ACN } & \text {. Por } & 1 \\ \text { ACNA } & \text {.ECO } & 1 \\ \text { IRP } & \text {. Hum } & 1 \\ \text { IPMI } & \text {. MCi } & 1 \\ \text { IPMI } & \text {. StYC } & 1 \\ \text { ACNB } & \text {.ECO } & 358\end{array}$

$\begin{array}{ll}\text { ACN } & \text {. Por } \\ \text { ACNA } & \text {. ECO } \\ \text { IRP } & \text {.Hum } \\ \text { IPMI } & \text {. MCI } \\ \text { IPMI } & \text {.StYC } \\ \text { ACNB } & \text {.ECO }\end{array}$

$\mathrm{ACN}$

$A C N$. Por

ACNA . ECO

IRP . Hum

IPMI .MCi

IPMI . StYC

ACNB . ECO

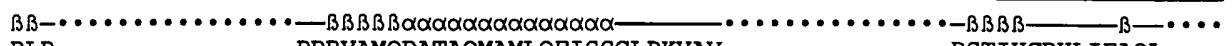

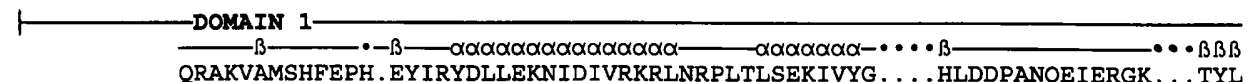
MSSTLREASKD. TLQAK. . . . DK. TYHYYSLPLAAKS . LGDITR. . LPKSLKVLLE . NLLRWQDGNSVTEEDIHALAGWL MSNPFAHLAEPLDPVQPGKKFFNLNKLEDSRYG . . . . . . IPFSIRVLAA. . AIRNCDEFLVKKQDIENILHWN MISSISLSQDKCKYLLYNNL. LVDEREN . . . . . . FLVSLTCSY . . ILFQKTIPYION . . . . . VSTLYD REALGLPHSDVFRQAKDVAESDRGFSLAQKMVGRACGVK 3 RLR . . . . . . . . PDRVAMQDATAQMAMLQFISSGLPKVAV . . . . . . . . . PSTIHCDHLIEAOL . . . 1 KNAH. ADREIA. . . . . Y YRPARVLMQDFTGVPAVVDLAAMREAVKRLGGDTA . . KVNPLS. PVDLVIDHSVTVDRFGDD 66 VTQH. KNIEVP ....... FKPARVILQDFTGVPAVVDFAAMRDAVKKLGGDPE . . . KINPVC. PADLVIDHSIQVDFNRRA KVWDDHVIDQQEDGTCLIYIDRHLVHEVTSPQAFEGLRNANRPVRRPD $\ldots \ldots \ldots \ldots \ldots \ldots$ CTLATVDHNIPTT $\ldots \ldots$ 8 KLFDAHVVFEAPNETPLLYIDRHLVHEVTSRRRLT.VCARTIAGTSAG . . . . . . . . KTFATMDHNVSTQ . . . 97 GIR. PGAYCEP. . . . . . KMTSVGSQDTTGPMTRDELKDLACLGFSADLVMQSFCHTAAYPKPVDVNTHHTLPDFI . . . . * $\mathbf{T}^{*}$

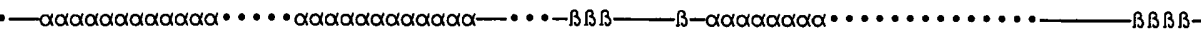
.GGEKDLRRAKDINO . . . . . EVYNFIATAGAKYG . . . VGFWRPGSGI IHOI ILEN . . . . . . . . . . . Y YAYPGVLLIGT EAFEENVRLEMERNH . . . . . ERYVFLKWGKQAFS . . RFSVVPPGTGICHQVNLEYLGKAVWSELQDGEWIAYPD . TLVGT DSLQKNQDLEFERNR . . . . . ERFEFLKWGSQAFH . . NMR I I PPGSGI IHQVNLEYLARVVFD . . QDG . . YYYPD. SLVGT . . TRKIFKNITTF IKEADSRTQCETLEQNIEAFGLTYFGMEDSRQGIVHVIGPEQG . . . . . . . . . FTLPATTVVCG $\ldots$ TKDINASGEMAR . . . IQMQELIKNCNEFGVELYDLNHPYQGIVHVMGPEQG . . . . . . . VTLPGMTIVCG

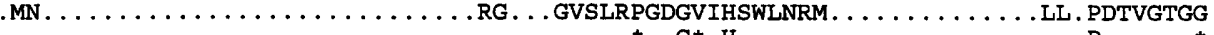
$\star \quad G * H$

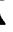

$-\alpha \alpha \alpha \alpha \alpha \alpha \alpha \alpha \alpha-\beta \beta \beta \beta-\alpha \alpha \alpha \alpha \alpha \alpha \alpha \alpha \alpha-\beta \beta \beta \beta-\beta \beta \beta \beta \beta \beta \beta \beta-$

$-\alpha \alpha \alpha \alpha \alpha \alpha \alpha \alpha \alpha \alpha \alpha \alpha \alpha \alpha-\beta \ldots \ldots \ldots$ DSHTPNGGGLGGICIGVGGADAVDVMAGI PWELKCPKVIGVKLTGSLSGWTSPKDVILKVAGILTVKGGT . . . . . . . DSHTTMINGLGVLGWGVGGIEAEAAMLGQPVSMLI PDVVGFKLTGKLREGITATDLVLTVTQMLRKHGVV . . . . . . . DSHTTMIDGLGILGWGVGGIEAEAVMLGQPISMVLPQVIGYRLMGKPHPLVTSTDIVLTITKHLRQVGVV . . . . . . DSHTSTHGAFGALAFGIGTSEVEHVLATQTLLQKKSKNMR IRVQGKALPGVTSKDIVLHI IGVIGTAGGT $\ldots \ldots \ldots \ldots$ DSHTATHGAFGALAFGIGTSEVEHVLATQTLKQGRAKTMKIEVTGNAAPGITAKDIVLAI IGKTGSAGGT . . . . . . DSHTRFP I . . G. ISFPAGSGLVAFAAATGVMPLDMPESVLVRFKGKMQPGITLRDLVHAI PLYAIKQGLLTVEKKGKKN

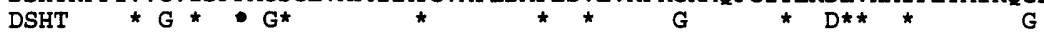
$\triangle \Delta \Delta \Delta$

..- - $\beta \beta \beta \beta-\alpha \alpha \alpha \alpha-\alpha \alpha \alpha \alpha \alpha \alpha \alpha \alpha \alpha \alpha-\beta \beta-\beta \beta \beta--\alpha \alpha \alpha \alpha \alpha \alpha \alpha \alpha \alpha-\alpha \alpha \alpha \alpha \alpha \alpha \alpha \alpha \alpha \alpha-\ldots \ldots \ldots \ldots \ldots \ldots$ . . GAIVEYHGPGVDSISCTGMATICNMGAEIGATTSVFPYN . HRMKKYLSKTGRADIA. NLADEF . . . . . . . . K . GKFVEFYGDGLDSLPLADRATIANMSPEYGATCGFFPID. AVTLDYMRLSGRSEDQVELVEKYA . . . . . KAQGMWR . GKFVEFFGPGVAQLSIADRATIANMCPEYGATAAFFPVD. EVSITYLVQTGRDEEKLKYIKKYL . . . . . . QAVGMFR .GCVIEFCGDTIAALSMESRMSICNMS IEAGARAGMVAPD . EVTFEYLRDKPLAPKGADWDRAV . . . . . . . KYW . . GHVVEFCGDAIRALSMEGRMTLCNMAIEMGAKAGLVAPD . ETTFNYVKGRLHAPKGRDFDEAV . . . . . . . . . EYW FSGR ILEIEGLPDLK. . VEQAFELTDASAERSAAGCTI KLNKEPI I EYLNSNIVLLKW. MIAEGYGDRRTLERRIQGMEK $\mathrm{G} * \mathbf{E} \mathbf{G}^{*} * \mathrm{E}^{*} \mathrm{~A}$

\section{+DOMAIN 3}

-DOMAT

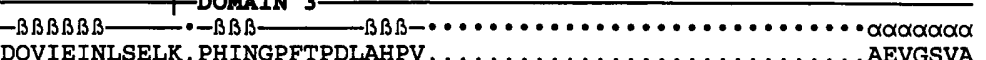
DH . . . . LVPDPGCHYDQVIEINLSELK. PHINGPFTPDLAHPV . . . . . . . . . . . . . . . . . . AEVGSVA NF........ PGDEPIF KS . . . . . LSSDADAKYDINVEINAADIA. PTLTWGTSPQDVVPITGSTPD. PAKIEDPIRRSAVQ . . . . . RALDYIG

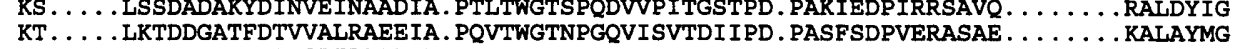
WLANPELLEADADAEYAAVIDIDLADIKEPILCAPNDPDDARPL $\ldots \ldots \ldots \ldots \ldots \ldots \ldots$. SAVQ $_{\star} \ldots$ G GEK. $\ldots \ldots \ldots$

$\alpha \alpha \alpha-\beta-\cdots-\beta \beta \beta \beta-\beta-\alpha \alpha \alpha \alpha \alpha \alpha \alpha \alpha \alpha \alpha \alpha \alpha \alpha \alpha \alpha \alpha-\beta \beta \beta \beta-\beta \alpha \alpha \alpha \alpha \alpha \alpha \alpha \alpha \alpha-\alpha \alpha \alpha \alpha \alpha \alpha-\beta$ EKEGWPLD . . . IRVGLIGSCTNSSYEDMGRSAAV. AKQALAHGLKCK. . SQFTITPGSEQIRATIERDGYAQVLRDVGGI NGHQYQLPDGAVVIAAITSCTNTSNPSVLMAAGLLAKKAVTLGLKRQPWVKASLAPGSKVVSDYLAKAKLTPYLDELGFN DNTEFTLAHGSVVIAAITSCTNTSNPSVMLGAGLLAKKAVDAGLNVMPYIKTSLSPGSGVVTYYLQESGVMPYLSQLGFD IAPNTPMEGVKVDKVFIGSCTNSR IEDLRAAAAVVK . . . . . GKRAAEWVDAMVVPGSGLVKRQAEREGLDKIFTDAGFD

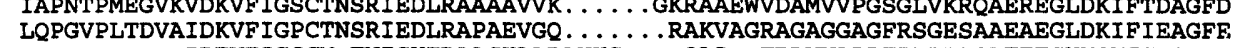
$\ldots \ldots \ldots \ldots$ IDEVFIGSCM. TNIGHFRAAGKLLDAHKG . . . . QLP . TRLWVAPPTRMDAAQLTEEGYYSVFGKSGAR

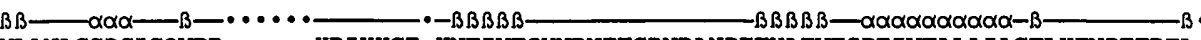
416 VLANACGPCIGQWDR . . . . . KDIKKGE. KNTIVTSYNRNFTGRNDANPETHAFVTSPEIVTALAIAGTLKFNPETDFL. 496 LVGYGCTTCIGNSGPLPDPIETAIKKGDLTVGAVLSGNRNFEGRIHPLVKTNWL. ASPPLVVAYALAGNMNINLASEPIG 496 VVGYGCMTCIGNSGPLPEPVVEAITQGDLVAVGVLSGNRNFEGRVHPNTRANYL.ASPPLVIAYAIAGTIRIDFEKEPLG 455 WREAGCSMCLGMNP . . . . . . DQLKPGE . . RCASTSNRNFEGRQGAGGRTHLV. . SPAMAAAAGIKGCLT . . . . . . .

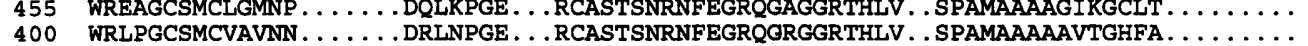
764 IEIPGCSLCMGNQARVADG . . . . . . . ATVVSTSTRNFPNRLGTG. . ANVFLASAELAAVAALIGKLPTPEEYQTYV

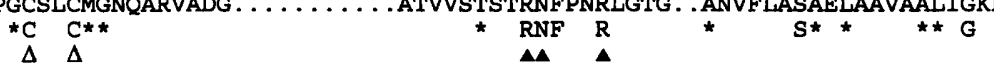

Fig. 6. For legend see facing page. 


$\begin{array}{llr}\text { ACN } & \text {. Por } & 488 \\ \text { ACNA } & \text {. ECO } & 575 \\ \text { IRP } & \text {. Hum } & 575 \\ \text { IPMI } & \text {. MCi } & 514 \\ \text { IPMI } & \text {. StYC } & 459 \\ \text { ACNB } & \text {. ECO } & 831 \\ & & \\ \text { ACNB } & \text {. ECO } & 1 \\ \text { ACNB } & \text {. ECO } & 29 \\ & & \\ & & \\ & & \\ \text { ACN } & \text {. Por } & 536 \\ \text { ACNA } & \text {. ECO } & 637 \\ \text { IRP } & \text {. Hum } & 638 \\ \text { IPMI } & \text {. MCi } & 565 \\ \text { IPMI } & \text {. StYD } & 1 \\ \text { ACNB } & \text {. ECO } & 109 \\ & & \end{array}$

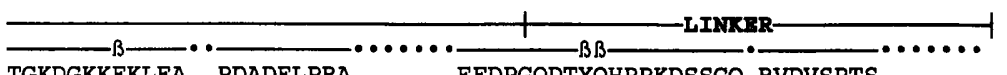

TGKDGKKFKLEA. . PDADELPRA. . . . . EEFDPGDTYOHPPKDSSGQ.RVDVSPTS . . . . . . . . . .

HDRKGDPVYLKDIWPSAQEIARAVE . $Q$.VSTEMFRKEYAEVFEGTAEWKGINVTRSDTYGWQED . . . . . . . .

VNAKGQQVFLKDIWPTRDEI . QAVERQY. VIPGMFKEVYQRIETVNESWNALATPSDKLFFWNSK . $\ldots \ldots \ldots \ldots \ldots$

. . DVRNMEVSEIPGTPKQSPRQ . . . . . EVVAEF. ESEEDDVDSSS . . VDSAPVATPPSTGD . . . . . . . . . 564

. . DIRSIK

AQVDKTAVDTYRYL.NFNQLSQYTEKADGVIFQTAV C-TERMINUS

N-TERMINUS MLEEYRKHVAERAAEGIAPKPLDANQMA ALVELLKNPPAGEEEFLLDLLTNRVPPGVDEAAYVKAGFLAAIAKGEAKSPLLTPEKAIELLGTMQGGYNIHPLIDALDD

$\beta \beta \beta \beta-\beta \beta-\beta \beta-\alpha \alpha \alpha \alpha \alpha \alpha \alpha \alpha-\beta \beta-\beta \beta \beta-\beta-\alpha \alpha \alpha \alpha \alpha \alpha \alpha \alpha \alpha-\bullet-\beta \beta \beta \beta \beta-\alpha \alpha \alpha \alpha \alpha \alpha-\ldots \ldots$ ACN .Por 630 WVVIGDENYGEGSSREHRALEPRHLGGRAIITKSFARIHETNLKKQG.LLPLTFADPADYNKI .....HPVDKLTIQGLK ACNA .ECO 764 LAVIAGKEYGSGSSRDWAAKGPRLLGIRVVIAESFERIHRSNLIGMG. ILPLEFPQGVTRKTLGL . . TGEEKIDIGDLQ IRP .Hum 764 LIVLAGKEYGAGSSRDWAAKGPFLLGIKAVLAESYERIHRSNLVGMG.VIPLEYLPGENADALGL. . . TGQERYTI IIPE IPMI .MCi 640 TLVCTGPNFGCGSSREHAPWAFNDFGIRCILAPSFADIFYNNCFKNG.MLPIVLPQDQLEAIAAEAK. . KGSEVEVDLIN IPMI .SEYD 72 SILLARENFGCGSSREHAPWALTDYGFKVVIAPSFADIFYGNSFNNO. LLPVTLSDAOVDELFALVKANPGIKFEVDLEA ACNB .ECO 233 LAYVGD.VVGTGSSRKSATNSVLWFMGD. DIP. HVPNKRGGGLCLGGKIAPIFF. NTMEDAGA......IPIEVDVSNL. .

$\mathrm{ACNB} . \mathrm{ECO} \quad 233$

$\begin{array}{lll}\text { ACN } & \text {. Por } & 704 \\ \text { ACNA } & \text {. ECO } & 840 \\ \text { IRP } & \text {. Hum } & 840 \\ \text { IPMI } & \text {. MCi } & 717 \\ \text { IPMI } & \text {. StyD } & 151 \\ \text { ACNB } & \text {. ECO } & 302\end{array}$

\begin{tabular}{|c|}
\hline 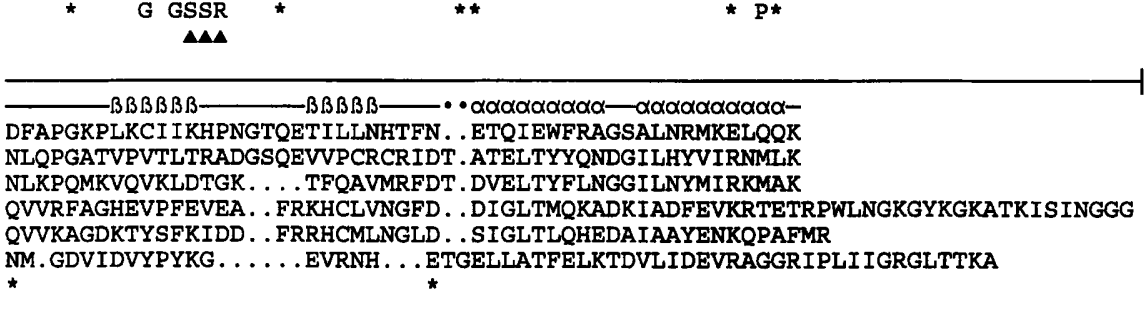 \\
\hline
\end{tabular}

Fig. 6. Multiple alignment of representative aconitase, IPMI and IRP amino acid sequences. The structural domains, $\alpha$ helices $(\alpha), \beta$-strands $(\beta)$ and random coil or turn $(-)$ of porcine aconitase are shown above the alignment. Insertiondeletions are indicated by dots. Residues which are identical in all sequences are shown in single-letter code below the alignment and conservatively substituted sites within the following groups: ILMV, AGPST, DENQ, FWY and HKR, are indicated by asterisks. Active-site residues $(\Delta)$ and the three cysteine residues $(\triangle)$ involved in ligand binding to the [4Fe-4S] cluster in porcine aconitase are indicated. The aligned sequences are porcine heart mitochondrial aconitase (ACN.Por), E. coli aconitase A (ACNA.ECO) and the rearranged aconitase B (ACNB.ECO), the human iron-responsive protein (IRP.Hum) and the IPMI of M. circinelloides (IPMI.Mci, revised according to Prodromou et al., 1992) and S. typhimurium (IPMI.StyC and IPMI.StyD subunits).

observations). It may be significant that the genes encoding the aerobic fumarase (FumA) and aconitase $(A c n A)$ are activated by iron and Fur, because this could provide a mechanism for controlling citric acid cycle activity in response to iron availability. It is also possible that one or both of the aconitases might function as an iron-responsive translational regulator analogous to mammalian IRP. Current work is aimed at studying the regulation of $a c n B$ gene expression using acnB-lacZ fusions, constructing and defining the phenotype of an $a c n B$ mutant, and investigating the properties of an acn $A$ $a c n B$ double mutant. This approach might identify specific metabolic roles for $A \subset n A$ and $A \operatorname{cn} B$, and explain why $E$. coli contains two aconitase isoenzymes.

\section{ACKNOWLEDGEMENTS}

We are very grateful to $A$. Moir and J. Keen for deriving the $\mathrm{N}$ terminal amino acid sequence of AcnB, D. Church for his assistance with database searches, and J. Green, S. C. Andrews, M. A. Quail and P. J. Artymiuk for advice and helpful discussions. The work was supported by grants from the Wellcome Trust and by a studentship from the Biotechnology Directorate of the Biotechnology and Biological Sciences Research Council to A. J.B.

\section{REFERENCES}

Bennett, B., Gruer, M. J., Guest, J. R. \& Thomson, A. J. (1995). Spectroscopic characterisation of an aconitase (AcnA) of Escherichia coli. Eur J Biochem 233, 317-326. 
Berlyn, M. B., Low K. B. \& Rudd K. E. (1996). Integrated linkage map of Escherichia coli $\mathrm{K}-12$, edition 9. In Eschericbia coli and Salmonella typhimurium: Cellular and Molecular Biology, 2nd edn. Edited by F. C. Neidhardt, R. Curtiss, III, J. L. Ingraham, E. C. C. Lin, K. B. Low, B. Magasanik, W. Reznikoff, M. Riley, M. Schaechter \& H. E. Umbarger. Washington, DC: American Society for Microbiology.

Cole, S. T. \& Guest, J. R. (1980). Genetic and physical characterization of lambda transducing phages $(\lambda f r d A)$ containing the fumarate reductase gene of Escherichia coli K12. Mol \& Gen Genet 178, 409-418.

Emery-Goodman, A., Hirling, H., Scarpellino, L., Henderson, B. \& Kuhn, L. (1993). Iron regulatory factor expressed from recombinant baculovirus: conversion between the RNA-binding apo-protein and Fe-S cluster containing aconitase. Nucleic Acids Res 21, 1457-1461.

Fujita, N., Mori, H., Yura, T. \& Ishihama, A. (1994). Systematic sequencing of the Escherichia coli genome: analysis of the 2.4-4.1 min (110,917-193,643 bp) region. Nucleic Acids Res 22, 1637-1639.

Gray, N. K., Quick, S., Goossen, B., Constable, A., Hirling, H., Kuhn, L. C. \& Hentze, M. W. (1993). Recombinant iron-regulatory factor functions as an iron-responsive-element-binding protein, a translational repressor and an aconitase. Eur J Biochem 218, 657-667.

Gribskov, M., Luthy, R. \& Eisenberg, D. (1990). Profile analysis. Methods Enzymol 183, 146-159.

Grosjean, H. \& Fiers, W. (1982). Preferential codon usage in prokaryotic genes: the optimal codon-anticodon interaction energy and the selective codon usage in efficiently expressed genes. Gene 18, 199-209.

Gruer, M. J. \& Guest, J. R. (1994). Two genetically-distinct and differentially-regulated aconitases (AcnA and AcnB) in Escherichia coli. Microbiology 140, 2531-2541.

Guest, J. R. (1992). Oxygen-regulated gene expression in Escherichia coli. J Gen Microbiol 138, 2253-2263.

Guest, J. R. (1995). The Leeuwenhoek Lecture, 1995. Adaptation to life without oxygen. Pbilos Trans R Soc Lond B Biol Sci 350, 189-202.

Guo, B., Yu, Y. \& Leibold, E. A. (1994). Iron regulates cytoplasmic levels of a novel iron-responsive element-binding protein without aconitase activity. $J$ Biol Chem 269, 24252-24260.

Hanahan, D. (1983). Studies on transformation of Escherichia coli with plasmids. $J$ Mol Biol 166, 557-580.

Henderson, B. R., Seiser, C. \& Kuhn, L. C. (1993). Characterization of a second RNA-binding protein in rodents with specificity for iron-responsive elements. J Biol Chem 268, 27327-27334.

Higgins, D. G. \& Sharp, P. M. (1989). Fast and sensitive multiple sequence alignments on a microcomputer. Comp Appl Biosci 5, 151-153.

Hirling, H., Henderson, B. R. \& Kuhn, L. C. (1994). Mutational analysis of the [ $4 \mathrm{Fe}-4 \mathrm{~S}]$-cluster converting iron regulatory factor from its RNA-binding form to cytoplasmic aconitase. EMBO J 13, 453-461.

Kennedy, M. C., Emptage, M. H., Dreyer, J.-L. \& Bienert, H. (1983). The role of iron in the activation-inactivation of aconitase. $J$ Biol Chem 258, 11098-11105.

Khoroshilova, N., Beinert, H. \& Kiley, P. J. (1995). Association of a polynuclear iron-sulfur center with a mutant FNR protein enhances DNA binding. Proc Natl Acad Sci US A 92, 2499-2503.

Klausner, R. D. \& Rouault, T. A. (1993). A double life: cytosolic aconitase as a regulatory RNA binding protein. Mol Biol Cell 4, 1-5.

Kohara, Y., Akiyama, K. \& Isono, K. (1987). The physical map of the whole E. coli chromosome: application of a new strategy for rapid analysis and sorting of a large genomic library. Cell 50, 495-508.

Laemmli, U. K. (1970). Cleavage of structural proteins during the assembly of the head of bacteriophage T4. Nature 227, 680-685.

Prodromou, C., Haynes, M. J. \& Guest, J. R. (1991). The aconitase of Escherichia coli: purification of the enzyme and molecular cloning and map location of the gene (acn). J Gen Microbiol 137, 2505-2515.

Prodromou, C., Artymiuk, P. J. \& Guest, J. R. (1992). The aconitase of Escherichia coli: nucleotide sequence of the aconitase gene and amino acid sequence similarity with mitochondrial aconitases, the iron-responsive-element-binding protein and isopropylmalate isomerases. Eur J Biochem 204, 599-609.

Reaney, S. K., Begg, C., Bungard, S. J. \& Guest, J. R. (1993). Identification of the $\mathrm{L}$-tartrate dehydratase genes ( $t t d A$ and $t t d B$ ) of Escherichia coli and evolutionary relationship with the Class I fumarase genes. J Gen Microbiol 139, 1523-1530.

Robbins, A. H. \& Stout, C. D. (1989). The structure of aconitase. Proteins 5, 289-312.

Rosenthal, E. R. \& Calvo, J. M. (1990). The nucleotide sequence of leuC from Salmonella typhimurium. Nucleic Acids Res 18, 3072.

Sambrook, J., Fritsch, E. F. \& Maniatis، T. (1989). Molecular Cloning: a Laboratory Manual, 2nd edn. Cold Spring Harbor, NY: Cold Spring Harbor Laboratory.

Schwartz, R. M. \& Dayhoff, M. O. (1979). Matrices for detecting distant relationships. In Atlas of Protein Sequences and Structure, pp. 353-358. Edited by M. O. Dayhoff. Washington, DC: National Biomedical Research Foundation.

Staden, R. (1982). An interactive graphics program for comparing and aligning nucleic acid and amino acid sequences. Nucleic Acids Res 10, 2951-2961.

Zheng, L. \& Dean, D. R. (1994). Catalytic formation of a nitrogenase iron-sulfur cluster. J Biol Chem 269, 18723-18726.

Received 12 September 1995; revised 17 October 1995; accepted 23 October 1995. 